\title{
INFLUENCE OF CORD BLOOD SERUM AND ACTOVEGIN ON THE REPRODUCTIVE FUNCTION OF COWS IN THE COMPARATIVE ASPECT
}

\author{
Irina Bondarenko \\ Department of Obstetrics and Surgery \\ Irinabondarencko173@gmail.com \\ Andrey Lazorenko \\ Department of Obstetrics and Surgery ${ }^{l}$ \\ Lazorenkoandrej@gmail.com \\ Oksana Shkromada \\ Department of Obstetrics and Surgery \\ oshkromada@gmail.com \\ ${ }^{1}$ Sumy National Agrarian University \\ 160 Herasyma Kondratieva str., Sumy, Ukraine, 40021
}

\begin{abstract}
The results of the study of the effect of cord blood serum and «Actovegin» (Takeda, Ukraine) on the reproductive function of cows in a comparative aspect are presented.

The aim of the study was to analyze the effect of cord blood serum and Actovegin on the reproductive function of uterine cows in a comparative aspect.

Materials and methods. The research was conducted during 2017-2020 in four dairy farms of Sumy region with tethered and untied maintenance. In 128 cows of different breeds and productivity, the timing of sexual cycling was studied and analyzed in comparison with the spontaneous sexual cycle with the use of cord blood serum and the drug «Actovegin» (Takeda, Ukraine).

Results. It was found that in cows with tethered content, the number of days from the introduction of $15 \mathrm{ml}$ of cord blood serum to the manifestation of the excitation stage was significantly less compared to the spontaneous manifestation of sexual desire (5.63 \pm 0.36 and $14.38 \pm 2.1$, respectively).

When cows with loose content were administered $10 \mathrm{ml}$ of cord blood serum in combination with the drug «Actovegin», the number of days before the manifestation of sexual cycling was lower by $18.3 \%$ compared with the rate of spontaneous sexual desire ( $4.31 \pm 0.38$ and $18.25 \pm 1.89$, respectively).

Conclusions. As a result of using $10 \mathrm{ml}$ of cord blood serum in combination with the drug «Actovegin», in cows of different productivity and under different housing conditions, the number of days before the onset of the stage of arousal is significantly reduced compared to the spontaneous manifestation of sexual desire.

Cows of different productivity and with different housing conditions come to the sexual desire significantly faster with the use of $15 \mathrm{ml}$ of cord blood serum compared to the spontaneous manifestation of sexual desire.
\end{abstract}

Keywords: cows, cord blood serum, actovegin, correction of reproductive function.

DOI: $10.21303 / 2504-5679.2021 .001834$

\section{Introduction}

Researchers are increasingly focusing on drugs of organic origin, which include the drug «Actovegin» and cord blood serum (CBS) $[1,2]$.

The advantages of umbilical cord blood are ease and safety of its obtaining; availability for immediate use of cryopreserved samples, relatively low probability of acute or chronic graftversus-host disease [2, 3].

Scientists claim that cord blood serum is an effective means for stimulating and regulating the processes of proliferation, differentiation and maturation of epithelial cells, normalization of the body's immune responses. In addition, CB serum stimulates repair, has anti-inflammatory antioxidant, adaptogenic, antihypoxic, anabolic and bacteriostatic effects associated with antibacterial factors such as IgG, lysozyme and complement [3, 4]. 
However, there are no data on the use of cord blood preparations to stimulate and correct the reproductive function of cows. Therefore, it is undoubtedly an urgent task to study the stimulating effect of cord blood serum compared and combined with «Actovegin» in order to accelerate the manifestation of the excitation stage.

Analysis of recent research and publications. Cord (placental, umbilical, fetal) is blood that remains in the vessels of the placenta and umbilical cord immediately after removal of the newborn from the mother's body. In fact, CB is an integral part of fetal blood $[5,6]$. Doctors call umbilical cord blood liquid gold, scientists - the greatest success story in the field of cell technology $[4,7]$.

$\mathrm{CB}$ - creates an internal environment of the fetus that is actively developing, ensuring the transport of biologically active substances of the placenta and fetal tissues, which in turn determine the growth and differentiation of embryonic cells and the regulation of metabolism. Due to the ability to implement in the body of the recipient all their inherent properties (proliferation and differentiation), CB cells are used as a temporary and long-term (depending on the degree of compatibility) graft. The purpose of the use of temporary grafts is the correction of hematopoiesis and immunopoiesis, stimulation of non-specific immune factors, activation of organs and systems that ensure the stability of homeostasis. CB contains $\alpha$-fetoprotein, $\alpha 2$-microglobulin fertility, trophoblastic $\beta 1$-glycoprotein associated with pregnancy $\alpha 2$-glycoprotein, uromodulin, chorionic gonadotropin, placental lactogen, progesterone and others $[5,6]$.

Scientists claim [6] that $\mathrm{CB}$ has an increased level of substances involved in the antioxidant system: carotenoids, ascorbic acid, tocopherols and others. This causes an increase in the resistance of $\mathrm{CB}$ plasma to $\mathrm{Cu}_{2}$ and induced lipid peroxidation. $\mathrm{CB}$ contains an increased composition of trace elements that are involved in various processes of cellular metabolism: potassium, calcium, magnesium, phosphorus, iron.

The amount of nickel, chlorine and zinc in the CB is almost no different from the amount of these elements in the blood of an adult. Glucose, lactate, creatine, elevated levels of betaine were found among low molecular weight substances $[6,8]$.

Till nowadays, there is enough information in scientific and clinical practice on the impact of $\mathrm{CB}$ on individual organs, systems and cell cultures, and on the body as a whole. A large number of biogenic stimulants based on $\mathrm{CB}$ have been developed, as umbilical cord blood contains a balanced complex of biologically active substances involved in induction, repression, reverse inhibition of various enzymes of organs and tissues of the recipient, thus affecting the metabolism not only but also on the body without severe pathology $[5,8]$.

$\mathrm{CB}$ also differs from adult blood in rheological and immunological characteristics [6, 9], coagulation parameters [7], and oxygen transfer, which allows the use of fetal erythrocytes in severe forms of hemorrhagic shock accompanied by secondary tissue hypoxia [3].

$\mathrm{CB}$ erythrocytes have increased transport and immune properties and contain a large amount of fetal hemoglobin enriched with oxygen. Because of this, erythrocytes of the CB are able to function in the bloodstream for a long time after transfusion $[7,10]$.

CB lymphocytes have a specific immunoreactivity, because on the surface of a one third of them, the so-called «zero lymphocytes», there are no markers for any immunocompetent cells, the rest do not have receptors for interleukin-2 [10, 11].

$\mathrm{CB}$ is enriched with immature stem cells - precursors that are not perceived by the donor as foreign and do not require individual selection, compared with the body's response during blood transfusion $[5,12]$.

$\mathrm{CB}$ serum is a unique biological medium that contains pro-enzymes, enzymes, receptors, adaptogens, growth factors, immunoregulatory agents, transport proteins, etc. CB serum cytokines (interleukins, interferons, colony-stimulating factor, tumor necrosis factor, transforming growth factor) are involved in the processes of immunoendocrine interaction of mother and fetus.

$\mathrm{CB}$ serum also contains reproductive hormones: chorionic gonadotropin, placental lactogen, prolactin, chorionic thyrotropic and adrenocorticotropic hormones, $\alpha$-melanocyte-stimulating hormone, and structural analogues of brain neuropeptides (endorphins), 12 endorphins and enkephalins $[9,13]$. 
Scientists claim that the concentration of the hormones mentioned above in the CB serum is much higher than in the blood of a non-pregnant adult, because it provides flexible regulation of vital processes during the perinatal period. The information written above partially explains the therapeutic effect of the use of drugs based on placental blood, including cryopreserved CB serum. It happens because the low temperature allows maintaining biologically active compounds in the native state and physiological ratios [14].

When studying the processes of freezing and storage of CB serum, the researchers found that with low-temperature $\left(-20^{\circ} \mathrm{C}\right)$ preservation, the quantitative indicators of the content of hormones of protein origin are slightly reduced compared to the baseline. The long-term effect of drugs made from cryopreserved $\mathrm{CB}$ serum on the body as a whole and on the embryonic and teratogenic effects was also studied. It has been determined that the drugs mentioned above do not have a negative effect on reproductive function and pregnancy, but reduce pre- and postimplantation overall embryonic mortality.

Scientists have positive experience in the use of cryopreserved CB serum for the treatment of chronic inflammatory processes (salpingitis, oophoritis, endometritis, pancreatitis, etc.). Analgesic and anti-inflammatory effect, restoration of immune and endocrine systems, improvement of cellular and humoral immunity was proven. The use of CB serum has a positive effect on repair processes, reduces the risk of complications due to the action of antibiotics and cytostatics, reduces the duration of treatment $[10,12]$.

$\mathrm{CB}$ plasma is also unique because it is enriched with a large number of vitamins, trace elements, various proteins, hormones, neuropeptides and other low molecular weight compounds that are absent in the blood of the adult body [13].

It is also unique that the $\mathrm{CB}$ plasma contains more than 60 specific placental proteins that act as enzymes, hormones, adaptogens, receptors, growth factors, immunoregulatory agents, and is saturated with a large number of peptides - structural analogues of brain neuropeptides and opioid peptides (endorphins and enkephalins) [13].

The most common, at present, is the ability to use CB as an alternative source of hematopoietic progenitor stem cells, because, despite the high content of many bio-and immunostimulants, the latter are in a balanced concentration and are a biologically active complex necessary for body development and normalization of metabolism in the case of its introduction into the body of an adult animal. Due to the above properties of the cell composition, CB and drugs made from it are increasingly used in clinical practice, and used as a whole CB and its components [14].

When choosing a source of stem cells, it is the CB that is preferred, because in this case there are no moral and ethical problems of its production. The ease of the mononuclear isolation procedure is also noteworthy, as is the fact that the content of stem and early progenitor cells does not differ from the number of the latter in the bone marrow, while the proliferative potential exceeds it. Stem cells are used in the treatment of about a hundred different diseases, including cancer of various localizations, genetic diseases, leukemia, immunodeficiency, cardiovascular disease, stroke, limb ischemia, multiple sclerosis, diabetes, liver cirrhosis, pancreatic necrosis, as well as chronic and autoimmune diseases. Umbilical cord blood reveals mesenchyme stem cells, which make up bones, cartilage, teeth and a special type of so-called pluripotent stem cells, which are no longer present in any body tissue and can be used in tissue engineering to create new organs to replace patients [10]. In recent years, hemangioblasts $(\mathrm{AC} 133+)$ have also been isolated from umbilical cord blood, which are used in tissue engineering of heart valves and vascular implants [15, 16].

$\mathrm{CB}$ has a unique subpopulation of lymphoid cells: a quantitative predominance of inactivated, immature and suppressor cells is registered, which prevents the emergence of a graftversus-host condition, even in the case of umbilical cord blood stem cells with incomplete HLA-compatibility. CB is widely used in the treatment of various types of anemia. It is proved that the use of $\mathrm{CB}$ stem cells is not limited to the restoration of the hematopoietic system. The body's response is unpredictable. It is possible to eliminate the pathology of nerve cells, restore the liver parenchyma and pancreatic cells, to normalize homeostasis and others. Mesenchyme stem cells under the conditions of cultivation in a special way are transformed into fibroblasts, cells of bone, adipose and fibrous tissue. The advantages of using CB include a reduced risk of transmission of some latent infections, no post-transfusion reactions and unlimited long-term storage in the frozen state [17]. 
Scientists have proven that the use of CB serum in gynecological disorders restores the hormonal balance of the reproductive system, and in contrast to hormone replacement therapy, does not cause suppression of ovarian steroidogenesis [18].

In addition to the $\mathrm{CB}$ serum, in our opinion, the drug of organic origin «Actovegin», developed by the Austrian company «Nycomed», deserves attention. The molecular weight of its components does not exceed $5 \mathrm{kDa}$. «Actovegin» is a deproteinized hemoderivative of calf blood that contains only physiological substances with a molecular weight $<5000 \mathrm{Da}$, such as low molecular weight peptides, amino acids, nucleosides, antioxidants, trace elements, anions and cations. «Actovegin» shows the following effects: metabolic, neuroprotective and microcirculatory by stimulating the process of utilization and transport of glucose; the process of capturing and utilizing oxygen. Deproteinized hemoderivative of calf blood activates the formation of adenosine diphosphate, adenosine triphosphate, creatine phosphate, amino acids (including glutamate, aspartate, gamma-aminobutyric acid). «Actovegin» also increases cellular energy metabolism, energy metabolism, stimulates and accelerates healing processes [8].

According to scientists, $[8,9]$ «Actovegin» helps to normalize blood circulation to the genitals, which provides active growth of the endometrium during the stage of excitation. The regenerative effect of the drug on the uterine mucosa in the treatment of endometritis has been proven.

The aim of the research was to determine and analyze the effect of cord blood serum and «Actovegin» on the reproductive function of the uterine population of cows in a comparative aspect. The results of research can be proposed as a way to restore and correct the reproductive function of the breeding stock of cows in farms with different forms of ownership and under different methods of keeping animals.

\section{Materials and methods}

The research was carried out in the following farms: for tethered keeping with productivity $<6000 \mathrm{~kg}$ : OJSC BP «Mykhailivka» of Lebedyn district of Sumy region (cows of (American) Brown Swiss breed), farm «Vitaliia» of Buryn district of Sumy region (Simmental cows), for loose housing with productivit $\mathrm{y}>6000 \mathrm{~kg}$ : LLC AF «Vladana» (cows of the Ukrainian black-spotted breed), and LLC AF «Lan» of the Sumy district of the Sumy region (cows of the Holstein breed).

Etiological factors, the state of neuroendocrine regulation of reproductive function of cows were the subject of research.

The object of research is the state of reproductive function of uterine cows.

128 clinically healthy cows aged 3-10 years, which developed endometritis or manure retention and were in a state of anaphrodisia, were divided into 8 groups that included 16 heads each. The diagnosis was established on the basis of general clinical examinations and obstetric and gynecological medical examinations.

All animal experiments comply with the recommendations of ARRIVE and were performed in accordance with the British Animal Act (scientific procedures) 1986 and comply with the guidelines for the protection of animals used for scientific purposes.

In order to correct and stimulate the manifestation of the excitation stage, cord blood serum was used. To obtain the CBS, during the successive stage of birth in cows, after removal of the fetus, blood was drawn from the umbilical cord vein using disposable syringes of large volume. Before that, hemostatic forceps were applied at a distance of 3-5 cm from the calf's navel. In case of rupture of the umbilical cord, hemostatic forceps were applied 2-3 centimeters above the rupture site, after which it was punctured with a vein of the umbilical cord. After settling, the formed serum was centrifuged and poured into $5 \mathrm{ml}$ sterile plastic tubes and subjected to cryopreservation in a freezer at $-18{ }^{\circ} \mathrm{C}$, which was stored for up to 3-4 weeks.

In order to compare the effect of cord blood serum on the stimulation of reproductive function of cows, we also used the drug «Actovegin» - a highly purified hemodialysate obtained by ultrafiltration from the blood of dairy calves.

The action of the drug «Actovegin» is aimed at the correction of bioenergetic disorders, suppression of inflammatory cell infiltrates, restoration of microcirculation in the tissues of the uterine mucosa. The main pharmacological property of this drug is to improve glucose transport 
and oxygen uptake into tissues, which causes the activation of aerobic oxidation processes, which in turn increases the energy potential of the cell $[8,9]$ (Fig. 1).

\begin{tabular}{|c|c|}
\hline $\begin{array}{c}\text { Methods of stimulation of sexual cyclicity } \\
\text { in groups with tethered keeping (cows } \\
\text { of (American) Brown Swiss and } \\
\text { Simmental breeds) }\end{array}$ \\
\hline Group 1 & $\begin{array}{c}10 \mathrm{ml} \text { of cord blood serum } \\
\text { subcutaneously, } n=16\end{array}$ \\
\hline Group 2 & $\begin{array}{c}15 \mathrm{ml} \text { of cord blood serum } \\
\text { subcutaneously, } n=16\end{array}$ \\
\hline $\begin{array}{c}10 \text { ml of cord blood serum } \\
\text { subcutaneously, combined with } \\
\text { actovegin 10 ml (400 mg) } \\
\text { intramuscularly, } n=16\end{array}$ \\
\hline Group 4 & $\begin{array}{c}\text { spontaneous manifestation of } \\
\text { sexual desire } n=16\end{array}$ \\
\hline
\end{tabular}

\begin{tabular}{|c|c|}
\hline \multicolumn{2}{|c|}{$\begin{array}{c}\text { Methods of sexual cycling stimulating in } \\
\text { groups with loose housing (Ukrainian } \\
\text { black-spotted and Holstein breeds) }\end{array}$} \\
\hline Group 5 & $\begin{array}{c}10 \mathrm{ml} \text { of cord blood serum } \\
\text { subcutaneously, } n=16\end{array}$ \\
\hline Group 6 & $\begin{array}{c}15 \mathrm{ml} \text { of cord blood serum } \\
\text { subcutaneously, } n=16\end{array}$ \\
\hline Group 7 & $\begin{array}{c}10 \mathrm{ml} \text { of cord blood serum } \\
\text { subcutaneously, combined with } \\
\text { actovegin } 10 \mathrm{ml}(400 \mathrm{mg}) \\
\text { intramuscularly, } n=16\end{array}$ \\
\hline Group 8 & $\begin{array}{c}\text { spontaneous manifestation of } \\
\text { sexual desire } n=16\end{array}$ \\
\hline
\end{tabular}

Fig. 1. The scheme of the experiment

In order to correct sexual cycling in 64 cows of (American) Brown Swiss and Simmental breeds with tethered keeping, the following schemes were used:

Animals of the first group (16 cows) were injected with $10 \mathrm{ml}$ of cord blood serum subcutaneously, once in the neck.

Sixteen cows of the second group: $10 \mathrm{ml}$ of cord blood serum subcutaneously, once in the neck and $10 \mathrm{ml}$ (400 mg) of «Actovegin» intramuscularly, once in the neck.

16 cows of the third group were injected with $15 \mathrm{ml}$ of cord blood serum subcutaneously, once in the neck.

In animals of the fourth group (16 cows), the timing of spontaneous sexual desire was taken into account.

Similarly to the written above, 64 cows of Ukrainian black-spotted and Holstein breeds with loose housing, the following reproductive correction schemes were used:

Animals of the fifth group (16 heads) were injected with cord blood serum subcutaneously, once in the neck, at a dose of $10 \mathrm{ml}$.

16 cows of the sixth group: $10 \mathrm{ml}$ of cord blood serum subcutaneously, once in the neck and $10 \mathrm{ml}(400 \mathrm{mg})$ of «Actovegin» intramuscularly, once in the neck.

16 cows of the seventh group were injected with $15 \mathrm{ml}$ of cord blood serum subcutaneously, once in the neck.

The timing of spontaneous sexual desire was taken into account in 16 animals of the eighth group.

The effectiveness of correction and stimulation was determined by the morpho functional state of the genitals of cows before insemination, by the time of onset of the stage of arousal, the onset of pregnancy, and the determination of the insemination index. The insemination index (the number of inseminations used for fertilization) was calculated by the formula:

$$
I i=K o: K n
$$

where $I i$ - insemination index; $K o$ - the number of inseminations used to fertilize the experimental group of cows; $K n$ - the number of cows in the experimental group that became pregnant.

The obtained digital material was processed by methods of variation statistics using Student's parametric t-test.

\section{Research results}

The obtained data presented in Table 1, show that the number of days before the manifestation of the excitation stage in the first group is significantly less (by $14.4 \%(p<0.003)$ than in the 
fourth group ( $5.63 \pm 0.36$ and $14.38 \pm 2.1$, respectively). However, the same index of the first group was probably higher (by $5.6 \%)(p<0.03)$ relative to the second group. The number of days from the correction of reproductive function to the manifestation of the stage of excitation in the second group was probably lower by $14.4 \%(p<0.01)$ for the index of the fourth group. The above-mentioned index was probably lower by $4.9 \%(p<0.03)$ in animals of the third group, compared with the second group.

Table 1

The effect of cord blood serum and actovegin on the reproductive function of cows in a comparative aspect

\begin{tabular}{|c|c|c|c|c|c|c|}
\hline \multirow{2}{*}{$\begin{array}{l}\text { A group } \\
\text { of ani- } \\
\text { mals }\end{array}$} & \multirow{2}{*}{$\begin{array}{l}\text { The number of days } \\
\text { from the correction of } \\
\text { reproductive function } \\
\text { to the manifestation of } \\
\text { the stage of excitation }\end{array}$} & \multicolumn{2}{|c|}{$\begin{array}{l}\text { Came to sexual desire again after the } \\
\text { correction of sexuality and insemination }\end{array}$} & \multicolumn{2}{|c|}{$\begin{array}{c}\text { Calved } \\
\text { (after two inseminations) }\end{array}$} & \multirow{2}{*}{$\begin{array}{c}\text { Insemi- } \\
\text { nation } \\
\text { index }\end{array}$} \\
\hline & & $\begin{array}{l}\text { Number of } \\
\text { animals }\end{array}$ & $\begin{array}{l}\% \text { of the total number } \\
\text { of animals in the group } \\
\qquad(n=16)\end{array}$ & $\begin{array}{l}\text { Number of } \\
\text { animals }\end{array}$ & $\begin{array}{l}\% \text { of the total number } \\
\text { of animals in the group } \\
\qquad(n=16)\end{array}$ & \\
\hline 1 & $5.63 \pm 0.36$ & 5 & 31.25 & 11 & 68.75 & 1.5 \\
\hline 2 & $4.88 \pm 0.27$ & 3 & 18.75 & 14 & 87.5 & 1.4 \\
\hline 3 & $3.86 \pm 0.36$ & 1 & 6.25 & 15 & 93.75 & 1.2 \\
\hline 4 & $14.38 \pm 2.1$ & 10 & 62.5 & 7 & 43.75 & 4.3 \\
\hline 5 & $5.93 \pm 0.6$ & 7 & 43.75 & 12 & 75.0 & 1.91 \\
\hline 6 & $5.56 \pm 0.4$ & 4 & 25.0 & 14 & 87.5 & 1.42 \\
\hline 7 & $4.31 \pm 0.38$ & 2 & 12.5 & 16 & 100.0 & 1.13 \\
\hline 8 & $18.25 \pm 1.89$ & 10 & 62.5 & 4 & 25.0 & 6.5 \\
\hline
\end{tabular}

The number of days from the correction of reproductive function to the manifestation of the stage of excitation in animals of group 3 was lower by almost $14.4 \%(p<0.001)$ compared to group 4 where it equaled $3.86 \pm 0.36$ and $14.38 \pm 2.1$, respectively.

The number of days from the correction of reproductive function to the manifestation of the excitation stage in group 5 was lower by $18.2 \%(p<0.001)$ compared with group $8(5.93 \pm 0.6$ and $18.25 \pm 1.89$ days, respectively). The same index probably differed in the 5 th and 7 th experimental groups by $5.9 \%(p<0.025)$, as well as in 6th and 8 th by $18.3 \%(p<0.01)$.

The number of days from the correction of reproductive function to the manifestation of the excitation stage in group 6 was probably lower by $5.6 \%(\mathrm{p}<0.04)$ compared to the fifth group.

The same indicator was $18.3 \%(p<0.001)$ lower in animals of group 7 compared to the eighth group ( $4.31 \pm 0.38$ and $18.25 \pm 1.89$, respectively).

The rate of overfeeding (ineffective insemination after correction of sexual cyclicity) with tethered keeping was as follows: 5 cows of group 1 came to sexual desire again, which is $39 \%$ more than group 2 and $81 \%$ more than group 3. The number of cows with feces in group 1 was $51 \%$ lower than in group 4.

The number of cows in group 2 that showed sexual desire again after the correction of sexual cycling and insemination was $39 \%$ higher than in group 3, however, it was $70 \%$ less than in group 4.

Only 1 cow of group 3 showed sexual desire again compared to 10 animals of group 4, which was $90 \%$ less.

With loose housing, 7 cows of group 5 came to the sexual desire again, which is $38 \%$ more than group 6 and $43 \%$ more than group 7. The number of cows with feces in group 6 was $51 \%$ lower than in group 7 and $70 \%$ more than in group 8 .

4 cows of group 6 showed sexual desire again, which is $30 \%$ more than the group 7 . Two cows of group 7 re-came to the sexual desire, which is $79 \%$ less than 10 animals of group 8 .

The number of calves born from cows after two inseminations was as follows: in group 1 it equaled 11 cows that gave birth to calves. It is $27.3 \%$ less than the result of the second group 14 cows, and $36.4 \%$ less than the result of the third group - 15 cows. The number of calves born from cows in group 3 is $57.1 \%$ more than born form 7 cows of the fourth group. 14 cows who gave 
birth to calves in the 2nd group of animals were $7.1 \%$ less than 15 cows of the third group, and $50 \%$ more than 7 cows of the fourth. $53.3 \%$ more cows were calved in group 3 compared to the fourth group.

12 cows of the fifth group were calved during tethered keeping. This is $16.7 \%$ less than 14 cows of the sixth group, and $33.3 \%$ less than 16 cows of the seventh group, and $66.7 \%$ more than 4 cows of the 8 th group.

Fourteen cows of the sixth group calved after correction of reproductive function. This is $12.5 \%$ less than in group 7 and $71.4 \%$ more than in the eighth group. $75 \%$ more cows of group 7 calved compared to the eighth group.

After analyzing the insemination index of experimental cows, we found that when cows were tethered in group 1, it was equal to 1.5 , which is $6.7 \%$ more than the result of group 2 (1.4) and $20 \%$ more than index of the third group (1.2). However, the same index was $65.1 \%$ less than the one of the fourth group $(4,3)$. In cows of group 2 , the insemination index was 1.4 , which is $14.3 \%$ more than in group 3 (1.2) and $67.4 \%$ less than in group four (4.3). The insemination index in cows of group 3 (1.2) was lower by $72.1 \%$ compared to the fourth group.

In loose housing: the insemination index of group 5 was 1.91 ; which is $25.7 \%$ more than the index of group 6 (1.4) and $40.8 \%$ more than the one of group 7 (1.13), and $70.6 \%$ less than the insemination index of the eighth group of cows (6.5). In cows of group 6 , the insemination index was 1.42 , which is $20.4 \%$ more than index of group 7 (1.13), and $78.25 \%$ less than the index of group 8 (6.5). The insemination index of cows of group 7 was lower by $82.6 \%$ compared to the eighth group (1.13).

\section{Discussion of research results}

Studies have shown that cord blood serum contains pro-enzymes, enzymes, receptors, adaptogens, growth factors, immunoregulatory agents, transport proteins and other multipotent components that affect the repair of damaged tissues [12]. Studies have proven the role of reproductive hormones and cytokines of CBS. The latter participate in the processes of immunoendocrine interaction of mother and fetus and provide flexible regulation of vital processes during the perinatal period, which to some extent explains the therapeutic effect of cryopreserved CB serum, as low temperature allows to maintain biologically active compounds in the native state and physiological correlations $[12,14]$.

It is known that one of the main mechanisms of action of cord blood serum is neurotrophic influence, modulation and correction of the processes of neoangiogenesis and inhibition of endometrial tissues $[13,14]$. CBS also participates in the process of minimizing the production of inflammatory cytokines and has a positive effect on the formation of the cytokine profile of the body $[19,20]$. The therapeutic effect of the drug «Actovegin», apparently, is largely due to the ability of its components to stimulate the consumption of oxygen and glucose by cells, which is of great importance in many pathological conditions $[8,9]$.

Thus, the use of CB serum and the combined use of CB serum and «Actovegin» allowed to restore the morphological structure of the endometrium as well as to restore the balance between activator factors and inhibitors of angiogenesis, which determines the optimal conditions for the formation of the maternal placenta [21, 22].

Study limitations. Limitation of research is an insufficient period of observation of experimental animals. Still, a plausible idea of the impact of applied techniques on the reproductive function of cows was obtained.

Prospects for further. The prospect of further research is to determine the effect of the applied methods of correction of reproductive function of cows on newborn calves. The prospect of further research is to optimize the use of selected methods for correcting the reproductive capacity of cows.

\section{Conclusions}

As a result of the use of $10 \mathrm{ml}$ of cord blood serum in combination with Actovegin, the number of days before the onset of the arousal stage in loose cows decreased by an average of 10.52 days $(p<0.001)$ compared with the spontaneous manifestation of sexual cycling. 
The number of days before the onset of the arousal stage was probably 13.94 days lower on average $(p<0.001)$, compared with spontaneous sexual desire in tethered cows with the combined use of cord blood serum and Actovegin.

The practical value of the obtained results is a significant reduction of the service period in the post morbid state of the uterine herd of cows.

\section{Conflict of interests}

The authors declare that they have no conflicts of interest.

\section{Financing}

The conducted research is a part of the research work of the Department of Obstetrics and Surgery of Sumy NAU on the creation of a system of comprehensive measures to restore, synchronize and stimulate the reproductive function of cattle and pigs (state registration number 0108U005029).

\section{References}

[1] Yan, T., Venkat, P., Chopp, M., Zacharek, A., Ning, R., Cui, Y. et. al. (2015). Neurorestorative Therapy of Stroke in Type 2 Diabetes Mellitus Rats Treated With Human Umbilical Cord Blood Cells. Stroke, 46 (9), 2599-2606. doi: http://doi.org/10.1161/ strokeaha.115.009870

[2] Buchmayer, F., Pleiner, J., Elmlinger, M. W., Lauer, G., Nell, G., Sitte, H. H. (2011). Actovegin®: a biological drug for more than 5 decades. Wiener Medizinische Wochenschrift, 161 (3-4), 80-88. doi: http://doi.org/10.1007/s10354-011-0865-y

[3] Panossian, A., Seo, E.-J., Efferth, T. (2019). Effects of anti-inflammatory and adaptogenic herbal extracts on gene expression of eicosanoids signaling pathways in isolated brain cells. Phytomedicine, 60, 152881. doi: http://doi.org/10.1016/j.phymed.2019.152881

[4] Sun, J., Wang, J., Pefanis, E., Chao, J., Rothschild, G., Tachibana, I. et. al. (2015). Transcriptomics Identify CD9 as a Marker of Murine IL-10-Competent Regulatory B Cells. Cell Reports, 13 (6), 1110-1117. doi: http://doi.org/10.1016/j.celrep.2015.09.070

[5] Zhang, J., Lv, S., Liu, X., Song, B., Shi, L. (2018). Umbilical cord mesenchymal stem cell treatment for crohn's disease: a randomized controlled clinical trial. Gut Liver, 12, 73-78. doi: http://doi.org/10.5009/gnl17035

[6] Wu, M., Zhang, R., Zou, Q., Chen, Y., Zhou, M., Li, X. et. al. (2018). Comparison of the Biological Characteristics of Mesenchymal Stem Cells Derived from the Human Placenta and Umbilical Cord. Scientific Reports, 8 (1). doi: http://doi.org/10.1038/ s41598-018-23396-1

[7] Van Pham, P., Dang, L. T.-T., Dinh, U. T., Truong, H. T.-T., Huynh, B. N., Van Le, D., Phan, N. K. (2013). In vitro evaluation of the effects of human umbilical cord extracts on human fibroblasts, keratinocytes, and melanocytes. In Vitro Cellular \& Developmental Biology - Animal, 50 (4), 321-330. doi: http://doi.org/10.1007/s11626-013-9706-1

[8] Brock, J., Golding, D., Smith, P. M., Nokes, L., Kwan, A., Lee, P. Y. F. (2018). Update on the Role of Actovegin in Musculoskeletal Medicine. Clinical Journal of Sport Medicine, 30 (1), 83-90. doi: http://doi.org/10.1097/jsm.0000000000000566

[9] Lee, P., Kwan, A., Nokes, L. (2011). Actovegin ${ }^{\circledR}$ - Cutting-edge Sports Medicine or «Voodoo» Remedy? Current Sports Medicine Reports, 10 (4), 186-190. doi: http://doi.org/10.1249/jsr.0b013e318223cd8a

[10] Riordan, N. H., Morales, I., Fernández, G., Allen, N., Fearnot, N. E., Leckrone, M. E. et. al. (2018). Clinical feasibility of umbilical cord tissue-derived mesenchymal stem cells in the treatment of multiple sclerosis. Journal of Translational Medicine, 16 (1). doi: http://doi.org/10.1186/s12967-018-1433-7

[11] Ren, H., Sang, Y., Zhang, F., Liu, Z., Qi, N., Chen, Y. (2016). Comparative Analysis of Human Mesenchymal Stem Cells from Umbilical Cord, Dental Pulp, and Menstrual Blood as Sources for Cell Therapy. Stem Cells International, $2016,1-13$. doi: http://doi.org/10.1155/2016/3516574

[12] Mann, L., Snowise, S., Morales, Y., Prabhu, S., Tseng, S., Grill, R. et. al. (2016). Neurological Outcomes after Human Umbilical Cord Patch for In Utero Spina Bifida Repair in a Sheep Model. American Journal of Perinatology Reports, 6 (3), e309-e317. doi: http://doi.org/10.1055/s-0036-1592316

[13] Kuchma, M. D., Kyryk, V. M., Svitina, H. M., Shablii, Y. M., Lukash, L. L., Lobyntseva, G. S., Shablii, V. A. (2015). Comparative Analysis of the Hematopoietic Progenitor Cells from Placenta, Cord Blood, and Fetal Liver, Based on Their Immunophenotype. BioMed Research International, 2015, 1-16. doi: http://doi.org/10.1155/2015/418752

[14] Pittenger, M. F., Discher, D. E., Péault, B. M., Phinney, D. G., Hare, J. M., Caplan, A. I. (2019). Mesenchymal stem cell perspective: cell biology to clinical progress. NPJ Regenerative Medicine, 4 (1). doi: http://doi.org/10.1038/s41536-019-0083-6

[15] Nagaishi, K., Mizue, Y., Chikenji, T., Otani, M., Nakano, M., Saijo, Y. et. al. (2017). Umbilical cord extracts improve diabetic abnormalities in bone marrow-derived mesenchymal stem cells and increase their therapeutic effects on diabetic nephropathy. Scientific Reports, 7 (1). doi: http://doi.org/10.1038/s41598-017-08921-y 
[16] McLaughlin, C. A., West, T., Hollowell, R., Skergan, N. N., Baker, J., Donner, H. et. al. (2019). Expanded Access Protocol of Umbilical Cord Blood Infusion for Children with Neurological Conditions. STEM CELLS Translational Medicine, 8 (S1). doi: http://doi.org/10.1002/sctm.12583

[17] Marston, W. A., Lantis, J. C., Wu, S. C., Nouvong, A., Lee, T. D., McCoy, N. D. et. al. (2019). An open-label trial of cryopreserved human umbilical cord in the treatment of complex diabetic foot ulcers complicated by osteomyelitis. Wound Repair and Regeneration, 27 (6), 680-686. doi: http://doi.org/10.1111/wrr.12754

[18] Kočí, Z., Výborný, K., Dubišová, J., Vacková, I., Jäger, A., Lunov, O. et. al. (2017). Extracellular Matrix Hydrogel Derived from Human Umbilical Cord as a Scaffold for Neural Tissue Repair and Its Comparison with Extracellular Matrix from Porcine Tissues. Tissue Engineering Part C: Methods, 23 (6), 333-345. doi: http://doi.org/10.1089/ten.tec.2017.0089

[19] Ferdous, K. M. N. U., Hasan, M. S., Kabir, K. A., Zahid, M. K., Islam, M. K., Hasanuzzaman, M. (2018). Use of Umbilical Cord flap for Closure of Gastroschisis. Journal of Shaheed Suhrawardy Medical College, 10 (1), 47-50. doi: http://doi.org/10.3329/ jssmc.v10i1.38904

[20] Yamamoto, E., Niimi, K., Fujikake, K., Nishida, T., Murata, M., Mitsuma, A. et. al. (2016). High-dose chemotherapy with autologous peripheral blood stem cell transplantation for choriocarcinoma: A case report and literature review. Molecular and Clinical Oncology, 5 (5), 660-664. doi: http://doi.org/10.3892/mco.2016.1011

[21] Doi, H., Kitajima, Y., Luo, L., Yan, C., Tateishi, S., Ono, Y. et. al. (2016). Potency of umbilical cord blood- and Wharton's jelly-derived mesenchymal stem cells for scarless wound healing. Scientific Reports, 6 (1). doi: http://doi.org/10.1038/srep18844

[22] Couto, P. S., Shatirishvili, G., Bersenev, A., Verter, F. (2019). First decade of clinical trials and published studies with mesenchymal stromal cells from umbilical cord tissue. Regenerative Medicine, 14 (4), 309-319. doi: http://doi.org/10.2217/rme-2018-0171

Received date 09.02.2021

(C) The Author(s) 2021

Accepted date 19.03.2021

This is an open access article

Published date 25.05.2021 under the Creative Commons CC BY license

How to cite: Bondarenko, I., Lazorenko, A., Shkromada, O. (2021). Influence of cord blood serum and actovegin on the reproductive function of cows in the comparative aspect. EUREKA: Health Sciences, 3, 101-109. doi: http://doi.org/10.21303/ 2504-5679.2021.001834 